\title{
Lymphoblasts 5 Percent or More of Bone Marrow Nucleated Cells
}

National Cancer Institute

\section{Source}

National Cancer Institute. Lymphoblasts 5 Percent or More of Bone Marrow Nucleated Cells. NCI Thesaurus. Code C142103.

A semi-quantitative microscopic finding indicating that 5 percent or more of the nucleated cells in a bone marrow sample are immature mononuclear cells of lymphoid origin. 